\title{
PENGGUNAAN ALAT BANTU JALAN SEBAGAI FAKTOR RESIKO PERASAAN TAKUT JATUH PADA LANSIA DI KOTA DEPOK
}

\author{
Oleh \\ Agustina Dominggas Modok ${ }^{1}$ dan Dwi Nurviyandari Kusuma Wati ${ }^{1}$ \\ ${ }^{1}$ Fakultas Ilmu Keperawatan, Universitas Indonesia, Kampus FIK UI, Jl. Prof. Dr. Bahder Djohan, \\ Depok, Jawa Barat - 16424, Indonesia \\ E-mail: tinamodok@yahoo.co.id
}

\begin{abstract}
ABSTRAK
Penurunan fungsi sistem muskuluskeletal pada lansia berakibat pada meningkatnya kejadian jatuh. Hal tersebut menimbulkan perasaan takut jatuh lansia. Penggunaan alat bantu jalan merupakan salah satu faktor resiko peningkatan perasaan takut jatuh. Penelitian ini bertujuan untuk menganalisis hubungan antara alat bantu jalan dengan perasaan takut jatuh. Desain penelitian yang digunakan adalah cross sectional dengan melibatkan 111 lansia di Kota Depok dengan menggunakan multistage random sampling. Perasaan takut jatuh dinilai dengan menggunakan instrument Falls Efficacy Scale- International (FES-I) dan analisis bivariat menggunakan uji statistic chi square. Hasil penelitian menunjukan ada hubungan antara penggunaan alat bantu jalan dengan perasaan takut jatuh ( $\mathrm{p}$ value 0,0001). Perawat perlu mengetahui cara melakukan skrining dan mengenal faktor resiko perasaan takut jatuh pada lansia.
\end{abstract}

Kata kunci: alat bantu jalan, Falls Efficacy Scale-International, perasaan takut jatuh. 


\title{
THE USE OF ROAD ASSISTANCE AS A RISK FACTOR OF FEAR FEELING FALLS IN ELDERLY IN DEPOK CITY
}

\author{
By \\ Agustina Dominggas Modok ${ }^{1}$ dan Dwi Nurviyandari Kusuma Wati ${ }^{1}$ \\ ${ }^{1}$ Faculty or Nursing, University of Indonesia Jl. Prof. Dr. Bahder Djohan, Depok, \\ West Java - 16424, Indonesia \\ E-mail: tina_modok@yahoo.co.id
}

\begin{abstract}
Muskuluskeletal system function decline in elderly result in increased incidence of falls. Falls can cause fear of falling in elderly. The use of a walking aid is a risk factor for the increase in fear of falling. The purpose of this study aimed to analyze the relationship between using walking aid with a feeling of fear of falling. The study design used is cross sectional, involving 111 elderly in Depok City using multistage random sampling. Fear of falling assessed using instrumental Falls Efficacy Scale- International (FES-I) and bivariate analysis using chi square statistic test. The results showed association between use of walking aid with fear of falling ( $p$ value $=0.0001$ ). Nurses need to know about risk factors and how to screening fear of falling in elderly.
\end{abstract}

Keywords: walker, Falls Efficacy Scale-International, fear of falling. 


\section{Latar Belakang}

Perasaan takut jatuh (fear of falling) pertama kali dijelaskan oleh Murphy dan Isaacs pada tahun 1982 sebagai sindrom setelah jatuh atau "post fall syndrome" (Jung, 2008). Bhala, O’Donnell dan Thoppil (1982) menjelaskan perasaan takut jatuh sebagai "ptophobia" atau suatu bentuk phobia terhadap aktivitas seperti berdiri dan berjalan. Touhy dan Jett (2012) menjelaskan perasaan takut jatuh sebagai "fallofhobia".

Gaxatte et al, (2011) menjelaskan perasaan takut jatuh sebagai bentuk retriksi terhadap beberapa jenis aktivitas seperti membungkuk, berusaha untuk mendapatkan sesuatu yang berada di atas kepala lansia, membatasi aktivitas di luar rumah terutama hal-hal yang berhubungan dengan kegiatan sosial misalnya kegiatan keagamaan, kegiatan sosial, dan mengunjungi teman atau keluarga.

Prevalensi perasaan takut jatuh (fear of falling) di masyarakat cukup tinggi. Lopes, Costa, Santos, Castro dan Bastone (2009) yang melakukan penelitian kepada 147 orang lansia berusia 60-92 tahun di Brazil dengan metode cross- sectional memperoleh hasil bahwa sebagian besar responden yaitu 133 lansia $(90,48 \%)$ melaporkan perasaan takut jatuh dalam setidaknya satu kegiatan tanpa memperhatikan riwayat jatuh dan hanya 80 orang lansia $(54,42 \%)$ yang memiliki riwayat jatuh.

Dias, Freire, Santos, Vieira, Dias dan Perracini (2011) dalam penelitiaan terhadap 130 orang lansia di Brazil memperoleh hasil bahwa sebesar $80,54 \%$ lansia melaporkan perasaan takut jatuh, dan 52,22\% melaporkan perasaan takut jatuh disertai dengan retriksi terhadap aktivitas karena perasaan takut jatuh tersebut.

Salah satu fektor resiko perasaan takut jatuh adalah penggunaan alat bantu jalan. Menurut Jette (2013), salah satu faktor resiko perasaan takut jatuh adalah penggunaan alat bantu jalan. Selain itu, Chu et al (2011) dalam penelitian menjelaskan bahwa sebesar $45 \%$ partisipan dengan perasaan takut jatuh menggunakan alat bantu jalan. Pernyataan ini dkuatkan oleh hasil penelitian Gaxatte et al (2011) bahwa penggunaan alat bantu jalan berhubungan dengan perasaan takut jatuh $(\mathrm{p}=0,02)$. Selain itu, hasil penelitian Uemura et al. (2014) yang melakukan penelitian terhadap 4474 lansia di Jepang memperoleh hasil bahwa ada hubungan yang signifikan antara alat bantu jalan dengan perasaan takut jatuh $(\mathrm{p}<0,001)$. 
Jette (2013) menjelaskan bahwa perasaan takut jatuh merupakan respon rasional terhadap munculnya bahaya yang menjadi langkah pertama untuk mencegah jatuh. Akan tetapi perasaan takut jatuh yang berlebihan berdampak terhadap status kesehatan lansia. Beberapa dampak dari perasaan takut jatuh (fear of falling) yaitu kerusakan identitas sosiall, ketidakmampuan fungsional, retriksi terhadap aktivitas (Yardley dan Smith, 2002); penurunan interaksi sosial, tingkat kemandirian yang rendah, morbiditas/mortalitas yang tinggi (Legster, 2002; Harding dan Gardner,2007); penurunan kinerja fisik dan distress psikologis, peningkatan risiko jatuh dan hilangnya kualitas kesehatan secara progresif (Scheffer, Schuurmans, Dijk dan Hooft, 2008).

Menurut Donoghue, Cronin, Savva, O’Regan dan Kenny (2013) perasaan takut jatuh berdampak pada kemunduran dari gaya berjalan yang kemudian berefek pada pembatasan aktivitas. Perasaan takut jatuh dapat mengakibatkan resiko jatuh di masa depan (Foran, McCarron \& McCallion, 2013; National Institute for Health and Care Excellence, 2013; WHO, 2007; Wijlhuizen, Chorus \& Rock, 2008; Touhy \& Jett, 2012). Berdasarkan uraian diatas, penelitian ini dilakukan untuk melihat adanya hubungan penggunaan alat bantu jalan dengan perasaan takut jatuh dengan pada lansia di Kota Depok.

\section{Metodologi}

Desain penelitian yang digunakan dalam penelitan ini adalah penelitan analitik korelasi dengan pendekatan cross sectional yang digunakan untuk menganalisa hubungan perasaan takut jatuh dengan penggunaan alat bantu jalan pada lansia di Kota Depok. Jumlah sampel pada penelitian ini adalah 111 orang responden yang dipilih dengan menggunakan cara multistage random sampling dan purposive sampling. Kriteria inklusi adalah lansia yang dapat berkomunikasi dengan bahasa Indonesia.

Berkaitan dengan etik penelitian peneliti menjelaskan tujuan dan manfaat dari penelitian kepada responden dan responden yang bersedia menandatangani lembar persetujuan menjadi responden. Selain itu, peneliti juga memperhatikan bahwa tidak ada resiko cedera yang terjadi akibat penelitian ini. Persetujuan izin penelitian juga telah diberikan oleh Pihak fakultas, Dinas Kesehatan Kota Depok dan Kesatuan Bangsa dan Politik Kota Depok. Peneliti melakukan pengambilan data dengan cara wawancara kuesioner kepada 
setiap responden. Kuesioner tersebut terdiri dari dua bagian yakni pertanyaan data demografi dan pertanyaan pada kuesioner Falls Efficacy ScaleInternational (FES-I). Hasil uji validitas kuesioner pada 20 responden menunjukkan bahwa nilai validitas 0,2960,844. Hasil uji reliabilitas memperoleh nilai cronbach's alpha $0,934$.

Analisis univariat digunakan untuk memperoleh gambaran distribusi usia, jenis kelamin, status ekonomi, status marital, tingkat pendidikan, riwayat jatuh dalam dua belas bulan terakhir, penggunaan jumlah obat-obatan dan perasaan takut jatuh. Sedangkan analisis bivariat digunakan untuk menganalisa hubungan perasaan takut jatuh dengan riwayat jatuh. Uji hipotesis yang digunakan adalah uji chi square dengan kemaknaan $p$ value $<0.05$. Hasil penelitian ditampilkan dalam bentuk tabel dan dinterpretasi secara diskriptif.

\section{Hasil}

Tabel 1 menunjukkan bahwa sebagian besar lansia di Kota Depok merupakan lansia muda (60-69 tahun), berjenis kelamin perempuan, menikah, memiliki tingkat pendidikan terakhir Tamat SD, memiliki status ekonomi < UMR $(\mathrm{Rp}$.
2.732.000,00), tidak memiliki riwayat jatuh, tidak menggunakan alat bantu jalan dan tidak menggunakan obat

Tabel 1 Distribusi Karakteristik Lansia di Kota Depok, Juni 2016 (n=111)

\begin{tabular}{|c|c|c|}
\hline Karakteristik & (n) & $\%$ \\
\hline \multicolumn{3}{|l|}{ Usia } \\
\hline Lansia muda (60-69 tahun) & 58 & 52,3 \\
\hline Lansia madya (70-79 tahun) & 41 & 36,9 \\
\hline Lansia tua ( $\geq 80$ tahun) & 12 & 10,8 \\
\hline \multicolumn{3}{|l|}{ Jenis Kelamin } \\
\hline Laki-laki & 38 & 34,2 \\
\hline Peempuan & 73 & 65,8 \\
\hline \multicolumn{3}{|l|}{ Status Marital } \\
\hline Menikah & 64 & 57,7 \\
\hline Janda/Duda/Cerai & 45 & 40,5 \\
\hline Tidak Menikah & 2 & 1,8 \\
\hline \multicolumn{3}{|l|}{ Pendidikan Terakhir } \\
\hline Tidak Sekolah & 38 & 34,2 \\
\hline Tamat SD & 41 & 36,9 \\
\hline Tamat SMP & 18 & 16,2 \\
\hline Tamat SMA & 12 & 10,8 \\
\hline Tamat PT & 2 & 1,8 \\
\hline \multicolumn{3}{|l|}{ Status Ekonomi } \\
\hline < UMR (Rp. 2.732.000,00) & 96 & 86,5 \\
\hline$\geq$ UMR (Rp. 2.732.000,00) & 15 & 13,5 \\
\hline \multicolumn{3}{|c|}{$\begin{array}{l}\text { Riwayat jatuh dalam } 12 \text { bulan } \\
\text { terakhir }\end{array}$} \\
\hline Tidak Pernah & 88 & 79,3 \\
\hline Pernah & 23 & 20,7 \\
\hline \multicolumn{3}{|l|}{ Penggunaan alat bantu jalan } \\
\hline Tidak & 96 & 86,5 \\
\hline $\mathrm{Ya}$ & 15 & 13,5 \\
\hline \multicolumn{3}{|l|}{ Penggunaan Jumlah obat } \\
\hline Tidak & 53 & 47,7 \\
\hline $1-2$ & 41 & 36,9 \\
\hline$\geq$ & 13 & 15,3 \\
\hline \multicolumn{3}{|l|}{ Perasaan takut jatuh } \\
\hline Tidak ada $(<24)$ & 53 & 47,7 \\
\hline Ada $(\geq 24)$ & 58 & 52,3 \\
\hline
\end{tabular}

Hasil uji normalitas Skewness menunjukkan data yang tidak terdistribusi normal dengan nilai tengah 24. Nilai tengah ini digunakan sebagai cut off point untuk mengaktegorikan perasaan takut jatuh. Sebagian besar lansia melaporkan perasaan takut jatuh. 
Hasil analisis bivariat pada tabel 2 menunjukan bahwa terdapat hubungan yang signifikan antara perasaan takut jatuh dengan penggunaan alat bantu jalan ( $p$ value $=0,0001)$

Tabel 2 Hubungan Penggunaan Alat Bantu Jalan dengan Perasaan Takut Jatuh dengan pada Lansia di Kota Depok, Juni 2016 $(n=111)$

\begin{tabular}{clll}
\hline $\begin{array}{c}\text { Penggun } \\
\text { aan alat } \\
\text { bantu } \\
\text { jalan }\end{array}$ & \multicolumn{2}{c}{$\begin{array}{c}\text { Perasaan takut } \\
\text { jatuh }\end{array}$} & P value \\
\cline { 2 - 3 } & $\begin{array}{l}\text { Tidak } \\
\text { ada } \\
(\boldsymbol{\%})\end{array}$ & $\begin{array}{c}\text { Ada } \\
(\boldsymbol{\%})\end{array}$ \\
\hline Tidak & $\begin{array}{l}53 \\
(47,7)\end{array}$ & $\begin{array}{l}43 \\
(38,7)\end{array}$ \\
\hline Ya & $0(0,0)$ & $\begin{array}{l}15 \\
(13,5)\end{array}$ \\
\hline \multirow{2}{*}{$* 0(.0 \%)$} & cell with expected count $<5$
\end{tabular}

\section{Pembahasan}

Berdasarkan hasil penelitian diperoleh bahwa sebagian besar lansia di Kota Depok melaporkan perasaan takut jatuh. Penelitian yang sama di Brazil oleh Dias, Freire, Santos, Viera, Dias dan Perracini (2011) yang melakukan penelitian terhadap 130 orang lansia juga memperoleh hasil bahwa sebagian besar lansia melaporkan perasaan takut jatuh. Kempen, Haastregt, McKee, Delbaere dan Zijlstra (2009) yang melakukan penelitian terhadap 540 lansia di komunitas Jerman memperoleh hasil bahwa hampir sebagian dari total responden melaporkan perasaan takut jatuh. Selain itu dalam penelitian Kim dan So (2013) terhadap 9033 orang lansia di komunitas di Korea yang berusia di atas 65 tahun memperoleh hasil sebagian besar lansia melaporkan perasaan takut jatuh

Jang, Cho, Oh, Lee dan Baik (2007) yang melakukan penelitian terhadap 732 lansia di komunitas Korea memperoleh hasil bahwa sebagian besar lansia melaporkan perasaan takut jatuh disertai retriksi terhadap aktivitas. Gaxatte et al (2011) yang melakukan penelitian terhadap 635 lansia dengan metode prospective study dari tahun 1995 sampai tahun 2006 di Prancis memperoleh hasil sebagian besar lansia melaporkan perasaan takut jatuh. Kesamaan dalam penelitian ini mungkin dikarenakan sebagian besar lansia dalam penelitian ini adalah perempuan, dan memiliki tingkat pendidikan yang rendah.

Hasil penelitian ini mendapatkan hasil bahwa ada hubungan antara penggunaan alat bantu jalan dengan perasaan takut jatuh. Hasil penelitian ini sejalan dengan hasil penelitian Uemura et al. (2014) di Jepang yang memperoleh hasil bahwa ada hubungan yang signifikan antara penggunaan alat bantu jalan dengan perasaan takut jatuh. Hasil penelitian ini juga sejalan dengan hasil penelitian Gaxatte et al. (2011) bahwa ada hubungan 
antara penggunaan alat bantu jalan dengan perasaan takut jatuh. Jara, Olmos, Abad, Heslop, Walker dan Ortiz (2012) yang melakukan penelitian terhadap 109 lansia di Spanyol juga mendapatkan hasil bahwa lansia yang menggunakan alat bantu jalan memiliki perasaan takut jatuh yang lebih tinggi dari lansia tanpa alat bantu jalan.

Keterbatasan peneliti dalam penelitian ini dimana peneliti mengalami kesulitan mengikuti jadwal Posbindu yang dikarenakan tidak sesuai dengan jadwal peneliti. Oleh sebab itu peneliti melakukan pengambilan data dari rumah ke rumah dengan pendampingan kader yang akhirnya tidak memungkinkan peneliti untuk mengambil data sesuai dengan perhitungan quota setiap RW sesuai dengan yang direncanakan. Oleh sebab itu peneliti melakukan penelitian dengan teknik purposive sampling sampai total sampel terpenuhi. Selain itu peneliti juga mengalami kesulitan saat melakukan wawancara kuesioner dimana ada beberapa pertanyaan yang tidak dapat dipahami oleh responden sehingga peneliti melakukan penjelasan lebih lanjut mengenai maksud dari pertanyaan tersebut.

\section{Kesimpulan}

Hasil penelitian ini menunjukan gambaran karakteristik lansia di Kota Depok dimana lansia dalam penelitian ini adalah lansia muda (60-69 tahun), sebagian besar responden berjenis kelamin perempuan, menikah, memiliki status ekonomi < UMR, tingkat pendidikan responden tamat SD, tidak memiliki riwayat jatuh dan tidak mengkonsumsi obat. Hasil penelitian ini menunjukkan bahwa hampir sebagian dari lansia di Kota Depok melaporkan perasaan takut jatuh. Hasil penelitian ini juga didapatkan kesimpulan bahwa terdapat hubungan yang signifikan penggunaan alat bantu jalan dengan perasaan takut jatuh.

Hasil penelitian ini juga memberikan informasi bahwasanya ada hubungan antara penggunaan alat bantu jalan dengan perasaan takut jatuh. Sehingga penyedia layanan kesehatan di masyarakat Kota Depok khususnya perawat dapat mengenali faktor resiko tersebut yang dapat mengakibatkan peningkatan perasaan takut jatuh pada lansia sehingga dalam memberikan pelayanan pada lansia pemberi layanan kesehatan diharapkan mampu meminimalisir resiko perasaan takut jatuh di masyarakat dan juga dapat mengembangkan berbagai intervensi untuk menurunkan resiko peningkatan perasaan takut jatuh pada lansia di masyarakat

\section{Ucapan Terimakasih}


Peneliti mengucapkan terimakasih kepada kepada Fakultas Ilmu Keperawatan Universitas Indonesia, Dinas Kesehatan Kota Depok, Kesatuan Bangsa dan Politik Kota Depok yang telah memberikan izin dalam penelitian ini.

\section{Referensi}

Chu, C. L., Liang, C. K., Chow, P. C., Lin, Y. T., Tang, K. Y., Chou, M. Y., Chen, L. K., Lu T., Pan, C. C. (2011). Fear of falling (FF): Psychosocial and physical factors among institutionalized older Chinese men in Taiwan. Archives of Gerontology and Geriatrics, 53 : e232-e236, doi:10.1016/j.archger.2010.12.018

Dias, R. C., Freire, M. T. F., Santos, E. G. S., Vieira, R. A., Dias, J.M. D., Perracini, M. R. (2011). Characteristics associated with activity restriction induced by fear of falling in community-dwelling elderly. Rev Bras Fisioter, 15 (5) : 406-13.

Donoghue, O. A., Cronin, H., Savva, G. M., O'Reggan, C., Kenny, R. A. (2012). Effects of fear of falling and activity restriction on normal and dual task walking in community dwelling older adults. Gait Posture, $38: 120-124$.

Foran, S., McCarron, M., McCallion, P. (2013). Expanding Assessment of Fear of Falling among Older Adults with an Intellectual Disability: A Pilot Study to Assess the Value of Proxy Responses. ISRN Geriatrics, Volume 2013, Article ID 493042, 9 pages, http://dx.doi.org/10.1155/2013/49304 2

Gaxatte, C., Nguyen, T., Chourabi, F., Salleron, J., Pardessus, V., Delabriere, I., Thevenon, A., Puisieux F. (2011). Fear of falling as seen in the multidisciplinary falls consultation. Annals of physical and rehabilitation medicine, 54 : 248-258, doi:10.1016.j.rehab.2011.04.002

Jang, S. N., Cho, S. I., Oh, S. W., Lee, E. S., Baik, H. W. (2007). Time since falling and fear of falling among community-dwelling elderly. International Psychogeriatric, 19 (6) : 1072-1083. doi:10.1017/S1041610206004807

Jara, J. P., Olmos, P., Abad, M. A., Heslop., P., Walker, D \& Ortiz, C. A. $R$ (2012). Diffrences in fear of falling in the elderly with or without dizziness. Maturitas, 73: 261-264

Jette, A. M. (2013). Fear of falling in older person. Toronto : Philips Lifeline

Jung, D. (2008). Fear of Falling in Older Adults: Comprehensive Review. Asian Nursing Research. 2 (8).

Kempen, G. IJM., Haastregt, J. CM., McKee, K. J., Delabere, K., Zijlstra, GA. R. (2009). Socio-demographic, health-related and psychosocial correlates of fear of falling and avoidance of activity in communityliving older persons who avoid activity due to fear of falling. $B M C$ Public Health, 9:170 doi:10.1186/1471-2458-9-170

Kim, S \& So, W. Y. (2013). Prevalence and correlates of fear of falling in Korean community-dwelling elderly subjects. Experimental Gerontology. Vol. 48 (1323-1328)

Legters, K. (2002). Fear of falling. Physical journal of the American Physical Therapi Association, 82 : 264-272.

Lopes, K.T, Costa, D. F, Santos, L. F. Castro, D. P, Bastone, A. C. (2009). Prevalence of fear of falling among a population of older adults and its correlation with mobility, dynamic balance, risk and history of falls. Revista Brasileira de Fisioterapia, 13 (3) : 223-9.

Scheffer, A. C. Schuurmans, M. J, Dijk, N. V, Hooft, T. V. (2008). Systematic review-Fear of falling : measurement strategy, prevalence, risk factors and 
consequences among older person. Age and Ageing, 32 : 19-24. doi:10.1093/ageing/afm169.

Touhy, T. A \& Jett, K. F. (2012). Ebersole and Hess's gerontological nursing and healthy aging. $3^{\text {rd }} \mathrm{Ed}$. Canada : Mosby Elsevier

Uemura, K., Shimada, H., Makizako, H., Doi, T., Tsutusmimoto, K., Yoshida, D, Anan, Y., Ito, T., ,,, Suzuki, T. (2014). Effects of mild global cognitive impairment on the prevalence of fear of falling in community dwelling older adults. Maturitas, 78: 62-66

Wijlhuizen, G. J., Chorus, A. M. J., dan Rock, M. H. (2008). Fragility, fear of falling, physical activity and falls among older persons : Some theoretical considerations to interpret mediation. Preventive Medicine, 46 : 612-614

World Health Association (WHO) (2007). WHO global report on falls prevention in older age.

Yardley, L., Smith, H. (2002). A

Prospective 